\title{
Valg i Kenya og Zimbabwe: Ligheder og paradokser
}

Holger Bernt Hansen

Både Zimbabwe og Kenya havde gamle herskere før de seneste omstridte valg. Begge havde siddet fast og voldeligt på magten i to årtier, og begge havde skabt en klientgruppe omkring sig gennem udbredt korruption. Alligevel vurderede Vesten dem vidt forskelligt: Kenya var håbet, Zimbabwe var håbløst

I 2000 var det almindeligt i Afrika at gøre status ved både at se tilbage på de seneste årtiers blandede demokratiske og udviklingsmæssige resultater og håbefuldt at vende blikket mod den nære, men dog stadig usikre fremtid.

Pendulet svingede mellem pessimismen fra fortidens erfaringer og en håbefuld optimisme influeret af, at der i det internationale samfund med de store donorer i spidsen var sat en ambitiøs dagsorden i form af årtusindmålene, som alle gode kræfter skulle samles om at realisere frem mod år 2015.

I Kenya og Zimbabwe svingede pendulet i 2000 dog til den pessimistiske side, ikke mindst når man ka- stede blikket på de autoriserede billeder af de to landes mangeårige $o g$ bedagede præsidenter.

I Kenya havde Daniel arap Moi siddet rimeligt solidt i State House siden 1978. Nok havde han måttet tage hensyn til de demokratiske vinde, der blæste over Afrika i begyndelsen af 1990'erne i slipstrømmen efter Den Kolde Krigs ophør og Sovjetunionens opløsning, ved at indføre flerpartisystem og en begrænsning af præsidentperiodernes antal til to. Men demokratiske spilleregler er jo til for at brydes, når penge og villigheden til at bruge de nødvendige magtmidler, endda voldelige midler, er for hånden.

Derfor vandt Daniel arap Moi to 
valg (i 1992 og 1997), og de fleste regnede med, at han let ville kunne klare hindringen med begrænsningen i terminer og stile mod 'third term' - et udbredt modefænomen blandt siddende afrikanske præsidenter.

I Zimbabwe overtog Robert Mugabe præsidentposten i 1980 efter en mangeårig kamp mod et hvidt mindretalsstyre. Mugabe er således stærkt rodfæstet i en befrielsesbevægelse, og hans position og regeringspartiets monopolisering af staten og førstefødselsret til magten finder sin forklaring i befrielsesideologien.

Mugabe har gennem alle årene fastholdt et system med en demokratisk fernis, hvilket ofte har vildledt omverdenen og virket som et skjold over for nabostaterne. Han har arbejdet gennem demokratiske procedurer (regelmæssige valg, folkeafstemninger om forfatningen etc.), men han har groft manipuleret med og misbrugt centrale institutioner som valgkommissionen, domstolene, sikkerhedsstyrkerne, medierne osv. Med hensyn til brug af voldelige midler har han overgået Moi især ved at inddrage hæren som et politisk redskab legitimeret af netop befrielsesideologien.

Alene præsidentportrætterne gjorde det derfor nærliggende $\mathrm{i}$ år 2000 at trække paralleller mellem Kenya og Zimbabwe, og den livlige kenyanske presse satte ligefrem de to navne på en enkelt formel: $M o i-$ gabe. Begge havde siddet fast og voldeligt på magten i to årtier, begge havde tilgodeset sig selv og deres nærmeste gennem kontrol over statens ressourcer, og begge havde skabt en klientgruppe omkring sig gennem udbredt korruption, hvilket udviklede et interessefællesskab om med næsten alle midler at fastholde magten.

I begge lande var der således omkring årtusindskiftet oparbejdet betydelige demokratiske underskud.

\section{Fælles fortid - forskellig dagsorden}

Sammenstillingen af de to lande giver også mening på baggrund af den fælles koloniale fortid.

For det første var de de to eneste kolonier med en betydelig gruppe af europæiske settlere og i forlængelse heraf en gruppe hvide farmere, der havde tilegnet sig den mest frugtbare jord. Som følge heraf blev for det andet afkoloniseringsprocessen og opnåelse af uafhængighed kompliceret og medførte voldelige opgør anført af modstandsbevægelser - i Kenya Mau Mau-opstanden under ledelse af legenden Jomo Kenyatta og i Zimbabwe etablering af en egentlig befrielsesbevægelse, ZANU-PF, med Robert Mugabe som den ledende kraft.

Der opstod således velorganiserede og højt mobiliserede grupper i de to samfund med langsigtede politiske konsekvenser til følge.

Endelig for det tredje fik de to 
lande en anderledes sammensat økonomi end andre afrikanske lande, men de stod samtidig tilbage med et uhyre kompliceret problem i form af nødvendige jordreformer, en mere retfærdig jordfordeling og spørgsmålet om ejendomsret til jord.

Kenya fik løst problemet på en tilsyneladende smidig måde ved en gradvis afrikansk overtagelse af de hvide farme, men skabte samtidig et væsentligt ulighedsproblem baseret på etniske skillelinjer, idet hovedaktørerne i Mau Mau-oprøret, Kikuyuer fra det centrale højland, der ved uafhængigheden i 1963 havde overtaget den politiske magt, også blev den økonomisk dominerende gruppe ved at sætte sig på farmene, der for flertallets vedkommende lå uden for deres kerneområde.

Herved kom der en væsentlig grad af ulighed ind i samfundet såvel økonomisk som etnisk. Der var skabt en slags herskende og privilegeret gruppe, som var lidet tilbøjelig til at dele med andre, og som på grund af indsatsen i uafhængighedskampen også tilkendte sig selv en førsteret til - med Kwame Nkrumahs udtryk - det 'politiske kongedømme'.

I Zimbabwe gav uafhængigheden i 1980 ikke anledning til samme smidige og gradvise løsning af det basale jordproblem. Trods de marxistiske hældninger i befrielsesideologien fastholdt Mugabe af pragmatiske grunde det eksisterende økonomi- ske grundlag for landets udvikling, idet få tusinde hvide farmere fortsatte den for landet givtige produktion på den mest frugtbare jord.

Løsningen blev efter aftale med den tidligere kolonimagt udskudt til en fælles løsning på et senere tidspunkt. Det lå også i befrielsesideologien, at Mugabe helt naturligt måtte prioritere overtagelsen af 'det politiske kongedømme' og fastholde befrielsesbevægelsens monopol herpå gennem maksimal udnyttelse af alle smutveje i den demokratiske overbygning.

\section{Indbygget modsætning}

Der var således indbygget en fundamental modsætning i hele denne uafhængighedskonstruktion, hvor blot en lille gnist kunne udløse en eksplosion. Den kom i slutningen af 1990'erne og havde sin baggrund i flere forhold, ikke mindst en klodset optræden fra en nytiltrådt engelsk udviklingsminister.

Det velkendte scenario startede med krigsveteranernes voldelige fordriven af flertallet af hvide farmere og den efterfølgende fordeling af farmene blandt inderkredsen omkring præsidenten, dvs. blandt ministre, og blandt lederne fra hær og politi.

I forbindelse med det militsprægede opgør med de hvide farmere opstod et nyt politisk parti, MDG (Movement for Democratic Change), med udgangspunkt i fagbe- 
vægelsen og under ledelse af Morgan Tsvangirai. Åbenlys opbakning og støtte til det nye parti fra hvide farmere gav Mugabe anledning til en meget håndfast antikolonial retorik med en forstærket polarisering mellem de forskellige grupper til følge.

Det er således karakteristisk for situationen i Zimbabwe omkring år 2000, at der ikke gennemførtes en jordreform med en mere rimelig fordeling af den frugtbare landbrugsjord.

Det fik som konsekvens, at den $\varnothing$ konomiske udvikling blev nedprioriteret, mens den politiske udvikling fik absolut primat. Befrielsesideologien og befrielsesbevægelsen i ZANU-PF-inkarnationen blev det statsbærende princip, mens oppositionen gennemgående blev set som forræderisk mod den anti-koloniale revolution.

De økonomiske og etniske modsætninger, som kendtes fra Kenya, var om ikke fraværende så i hvert fald betragtet som mere marginale størrelser helt overskygget af befrielsesideologiens hegemoni. Karakteristisk for Zimbabwe bliver det, at den politiske dagsorden klart overordnes den økonomiske og sociale dagsorden, som faktisk hægtes af, hvor situationen i Kenya mere er karakteriseret ved, at de kører parallelt.

Denne forskel peger på et væsentligt problem generelt for Afrika: forholdet mellem politisk udvikling og demokratisering på den ene side og økonomisk vækst og reducering af fattigdom på den anden.

Hvad kommer først, og hvilken af dem udgør trækkraften i udviklingen?

\section{Dansk tilvalg og fravalg}

Uanset de mange ligheder mellem de to lande var den netop fremhævede forskel central i den danske beslutningsproces, da den nytiltrådte VK-regering i begyndelsen af 2002 foretog en revision af den danske bistandspolitik og fremlagde nye prioriteter. Nedskæringer i bistandsbudgettet medførte en reducering i antallet af samarbejdslande, og såvel Kenya som Zimbabwe kom i spil.

I Kenya var omfanget af bistandsindsatsen blevet betydeligt reduceret gennem 1990'erne, og der arbejdedes efter den såkaldte Kenya-model, hvor midlerne kanaliseredes uden om regeringen og direkte til modtagerne gennem lokale myndigheder og frivillige organisationer.

I Zimbabwe skete også nogle omlægninger, men trods politiske vanskeligheder kunne bistandsaktiviteterne i vid udstrækning gennemføres og nå ud til målgrupperne.

Når det alligevel besluttedes at fastholde Kenya og trække sig helt ud af Zimbabwe, indgik der uden tvivl i beslutningen en vurdering af, hvorvidt den politiske dagsorden og økonomiske udvikling stadig var sideordnede og udgjorde parallelle forløb, hvilket var tilfældet i Kenya 
om end med ringe grad af synergi, hvorimod Zimbabwe havde nedskaleret økonomisk udvikling og ensidigt prioriterede den politiske befrielsesdagsorden.

I vurderingen indgik tillige, om der var udsigt til politiske ændringer især i form af styrket demokratisering, såkaldt 'regime change', således at den politiske arena kunne udgøre en større 'trækkraft' i realiseringen af udviklingsmålene.

Også på dette punkt faldt Kenya positivt ud, mens Zimbabwe fortsatte i den nedadgående spiral med Mugabe-regimets fastholden af magtmonopolet gennem stigende voldsanvendelse.

Den positive danske vurdering af Kenya blev bekræftet allerede ved valget i slutningen af 2002, hvor 'regime change' blev en realitet. Først og fremmest måtte Daniel arap Moi trods forsøg på det modsatte respektere en ny politisk realitet og opgive en 'third term'. Væsentligst var, at oppositionen havde lært af fortidens fejltagelser og havde indgået en 'regnbuekoalition' med opbakning bag en fælles kandidat.

Veteranpolitikeren Mwai Kibaki blev valgt for en femårig periode med et mandat baseret på konsensus mellem de forskellige grupperinger til et politisk og økonomisk reformprogram, hvor spredning af den politiske magt og kampen mod korruption skulle være hovedpunkter.

Begejstringen - for ikke at sige eu- forien - indadtil og blandt eksterne samarbejdspartnere var stor, idet Kenya nu fik en ny start med sammenhæng og synergi mellem den politiske arena og den økonomiske vækst. Resultaterne viste sig da også hurtigt i form af imponerende vækstrater og stor uafhængighed af ekstern bistand, og succesen blev ikke overskygget af, at de politiske reformer stod i stampe på grund af de følgende års ustabile og skiftende koalitioner mellem partier og interessegrupper.

Det var en udbredt opfattelse, at Kenya som følge af den stedfundne 'regime change' var ved at blive en succeshistorie med status som Afrikas tredje største økonomi, og at en sammenligning med Zimbabwe blev mindre og mindre relevant.

\section{Valget i Kenya}

På denne baggrund kom det som en overraskelse og næsten som et chok, at valget i Kenya 27. december 2007 fik katastrofale konsekvenser. Parlamentsvalget og præsidentvalget fik modsatte udfald, hvilket kun kunne forklares ved udbredt svindel ved selve optællingen (af The Economist betegnet som 'massaged figures').

Det medførte meget alvorlige opgør mellem de store etniske grupper, der nærmest havde karakter af 'ethnic cleansing'. Forskellige militser, der var overraskende velforberedte, førte an i, hvad der udartede til et voldsorgie, der resulterede i ca. 


\section{HOLGER BERNT HANSEN}

500 dræbte og en halv million internt fordrevne. Kun sikkerhedsstyrkernes meget håndfaste nedkæmpning af urolighederne hindrede en borgerkrig og en almindelig opløsning af landet.

Hvorfor nu denne overraskelse og store skuffelse over de seneste måneders udvikling i Kenya blandt donorer og i det internationale samfund i almindelighed, hvor sammenligningen med Zimbabwe nu igen er blevet ført frem?

Et væsentligt svar ligger $i$, at mens man i Zimbabwes tilfælde har vurderet udviklingen realistisk og pessimistisk, har man betragtet Kenya som 'et demokratisk fyrtårn' og overset de advarselssignaler, som jæunligt har været der gennem hele den sidste valgperiode. Den politiske og $ø$ konomiske udvikling forblev ikke ligestillede, idet kampen om 'det politiske kongedømme' i stigende grad var blevet det væsentlige og førte til et 'valgkup' gennemført af koalitionen omkring den siddende præsident Kibaki med afkobling af alle hensyn til den økonomiske udvikling, idet fastholden af magten var blevet det primære.

Dette bunder i to underliggende faktorer, som er blevet overset i euforien over Kenya efter skiftet $i$ 2002. For det første var der med Kibaki-regimet sket en økonomisk og etnisk koncentration af magten. Kikuyu var efter Moi-årene vendt tilbage til det politiske centrum, og de udgjorde som tidligere fremhævet også den økonomisk privilegerede elite. Og deres opfattelse af en given fødselsret til magten blev underbygget af en slags etnisk baseret befrielsesideologi med Mau Mau-oprøret som grundlag.

For det andet var der trods megen retorik ikke sket strukturelle ændringer i det kenyanske samfund og end ikke tilløb til at gennemføre bebudede reformer, primært en jordreform. Uligheden og den ulige fordeling af goder bestod uændret, og bevidstheden herom blev øget gennem de demografiske ændringer med stor befolkningsvækst, et stigende antal unge arbejdsløse, forringede muligheder for uddannelse og job og generelt en stigende ulighed.

\section{Etniske skillelinjer}

Det afgørende element i Kenya har været, at uligheden og de stigende spændinger fik deres stærkeste udslag og afløb i de etniske skillelinjer (42 forskellige etniske grupper, der kan opdeles i 5 større grupper ud fra visibilitet og aktivitet). Konflikten i Kenya er i udgangspunktet ikke en etnisk konflikt, men de etniske forskelle aktiveres af ulighederne i samfundet og misbruges af politikerne i kampen om magten, og for befolkningen udgør det etniske tilhørsforhold under usikre vilkår den naturlige reference og identitet og bliver grundlaget for handling.

De senere års medieeksplosion, herunder en række lokalradioer, 
har yderligere bidraget til hele denne etniske bevidstgørelse.

Mere uventet har været omfanget af det voldsorgie, som på etnisk grundlag har gennemtrængt alle samfundets institutioner i chokerende grad, inklusive universiteter.

Men det skal også ses i en akkumuleret sammenhæng. Det er først under krisen, at man for alvor har set etniske militser i aktion rekrutteret fra det stigende antal unge arbejdsløse og - nok så alarmerende med mere eller mindre direkte støtte udefra og med forbindelse til ledende politikere.

Hertil kommer, at vold har været et almindeligt anvendt middel i kenyansk politik siden kolonitiden og opgøret med Mau Mau. En ledende forsker er endda gået så vidt som til at hævde, at der i Kenya eksisterer en voldskultur, som har været brugt i forbindelse med alle valg i Kenya.

\section{Både paralleller og forskelle}

Sammenligningen med Zimbabwe er derfor igen nærliggende og forstærkes af de mange paralleller til situationen i Zimbabwe forud for, under og efter valget den 29. marts 2008.

Der har været klare advarsler om, at Kenya kunne udvikle sig til et nyt Zimbabwe på grund af uregelmæssighederne ved selve valghandlingen og det efterfølgende 'valgkup', hvor det siddende styre med manglende respekt for gængse demokratiske principper og spilleregler har fastholdt sin ret til magten, og hvor de efterfølgende uroligheder med militsernes hærgen og sikkerhedsstyrkernes unødvendigt hårde magtanvendelse har bragt landet på randen af opløsning.

Til forståelsen af situationen i begge lande er det en afgørende og lærerig faktor, at helt centrale institutioner til garanti af demokratiets spilleregler som valgkommissionen og domstolene ikke har de fornødne midler og ej heller status og uafhængighed til at varetage deres funktioner.

Nok var der interne og eksterne valgobservatører, men når de øverste institutioner, der skulle have myndigheden til at gribe ind, ikke fungerer ordentligt eller er allieret med de siddende magthaverne, bliver ethvert valgresultat kontroversielt og utroværdigt - i øvrigt en erfaring med almen afrikansk gyldighed.

Lige så væsentligt er det at trække de punkter frem, som sætter de to situationer i relief:

For det første fulgte valgsituationen i Kenya og den efterfølgende voldsanvendelse et etnisk udgangspunkt med militslignende grupperinger af unge, der førte an i volden, hvorimod de etniske modsætninger stort set var fraværende i Zimbabwe, hvor volden såvel før, under og efter valget er udført af sikkerhedsstyrkerne og krigsveteranernes militser, der helt kontrolleres af regeringen. 


\section{HOLGER BERNT HANSEN}

Hvor hæren i Kenya er politisk neutral, er den i stigende grad et politiseret instrument for Zimbabwes regering, og der er tale om en stigende militarisering af hele styret.

For det andet er risikoen for en tilsvarende voldelig reaktion i Zimbabwe begrænset: dels på grund af regeringens monopol på magtapparatet og dens uhæmmede brug heraf over for oppositionsgrupper, der efterhånden er underkuede $\mathrm{og}$ frygtsomme, dels på grund af vanskeligheden ved at mobilisere oppositionen på grund af folkeflytninger internt og især tre millioner flygtninge (en tredjedel af befolkningen) i nabolandene, først og fremmest Sydafrika.

Dette hænger sammen med en tredje helt afgørende forskel. Hvor polariseringen i Kenya som tidligere fremhævet følger 'etno-økonomiske' skillelinjer, er den i Zimbabwe ensidigt markeret af befrielsesideologien, som sætter de væsentlige demokratiske principper ud af kraft.

Derfor kunne Mugabe, da han var kommet sig efter det første valgchok, slå fast, at han og bevægelsen aldrig vil overlade magten til oppositionen, der totalt mangler legitimitet. Såvel politiets som hærens ledelse, samlet i 'the Joint Operational Command', har ved flere lejligheder givet kontant udtryk for, at de ikke kan acceptere andre end Mugabe og ZANU-PF som ledere af landet.

Hvis et omvalg derfor fik et ikke acceptabelt udfald, var der en nær- liggende risiko for et militærkup, specielt da militæret allerede var rykket tæt på magtens centrum gennem deres tilstedeværelse i de enkelte ministerier.

\section{Muligheder for konfliktløsning}

Specielt sidstnævnte forskel spiller ind, når vi vender os mod løsningsmulighederne for de to kriser. Befrielsesideologiens legitimering af et magtmonopol og Zimbabwes medlemskab af et de facto eksisterende 'befrielsesideologisk netværk' bestående af staterne i det sydlige Afrika har gjort styret resistent over for internationalt pres og nærmest handlingslammet en organisation som SADC (Southern African Development Community), der ellers har et mandat til at virke som mægler og garant for den demokratiske proces med Sydafrikas præsident, Thabo Mbeki, som leder og mægler.

I Kenya var der en anden baggrund for styrets første hårdnakkede afvisning af hjælp til konfliktløsning og mægling udefra. Styret kunne ikke omgøre resultatet af parlamentsvalget, som gav oppositionspartierne et flertal til at vælge formanden.

Men samtidig stod den regerende koalition urokkeligt fast på, at den siddende præsident Kibaki havde vundet præsidentvalget og derfor fortsat var statsoverhoved med forfatningsgaranterede beføjelser til alene at udpege en regering. Derfor 
handlede styret hurtigt og besatte alle nøgleposterne i regeringen, mens man på arrogant vis afviste behovet for international mægling. Eksempelvis udtalte et ledende medlem af den hårde kerne omkring præsidenten, at hvis formanden for Den Afrikanske Union, Ghanas præsident Kufuor, skulle komme forbi, ville han altid være velkommen til the hos præsidenten.

Når situationen udviklede sig anderledes, skyldes det først og fremmest omfanget af den etnisk baserede vold, der i nogles øjne skabte mindelser om folkemordet i Rwanda. Selv om dette ikke var en korrekt vurdering, kunne det ikke overskygge en voksende humanitær katastrofe med en halv million internt fordrevne, ej heller en situation, der mindede om 'ethnic cleansing'.

Der var altså ikke blot tale om en valgkrise og en demokratisk krise med voldelige overtoner, men en krise, hvor borgerkrig og landets falden fra hinanden var rykket tæt på i den i forvejen sårbare og kriseprægede østafrikanske region. Derfor har de tunge aktører inden for det internationale samfund haft et helt andet grundlag for at øve pres, end tilfældet har været i Zimbabwe.

\section{Afrikansk organ som mægler}

Dernæst har det som den anden faktor været afgørende, at Den Afrikanske Union (AU) blev udpeget som det organ, der skulle mægle mellem de stridende parter. Uanset at den hårde kerne omkring præsidenten lagde talrige hindringer i vejen, var det i længden ikke muligt selv med en Zimbabwe-lignende retorik at afvise et afrikansk organ med dets særlige autoritet.

Hertil kommer som en tredje faktor det personlige element i situationen: Dels udpegede AU Kofi Annan, FN's nyligt afgående afrikanske generalsekretær, til at stå i spidsen for en mæglingsmission, dels var nabolandet Tanzanias præsident, Jakaya Kikwete, nyligt blevet valgt til AU's formand. Som kommende fra et naboland med en baggrund som legitimt valgt statsoverhoved har han optrådt med en autoritet, som selv den hårde kerne har måttet bøje sig for.

Alligevel forsøgte den hårde kerne på næsten bizarre måder at modarbejde Kofi Annan, og kun hans store diplomatiske erfaring og næsten endeløse tålmodighed bragte et resultat for dagen i form af en national enhedsregering bestående af de to store partikoalitioner. Det omtvistelige valgresultat måtte accepteres som det eneste mulige grundlag, hvilket har betydet, at præsident Kibaki fortsætter uændret med de store magtbeføjelser, som forfatningen tillægger ham.

Det nye er, at oppositionslederen Raila Odinga indtager en nyoprettet post som premierminister med beføjelser til at lede en særdeles talstærk regering, hvori hans parti har 


\section{HOLGER BERNT HANSEN}

fået et antal medlemmer på gennemgående mindre betydningsfulde poster.

Samtidig er det vedtaget, at der skal gennemføres et langsigtet reformprogram omfattende en forfatningsændring, en jordreform og en mindskelse af ulighederne i samfundet, altså reformer på de områder, som har udløst den aktuelle krise.

Den eksterne pression bidrog på afgørende vis til at løse en akut og alvorlig krise, men de særlige omstændigheder, primært det tilranede valgresultat som det givne udgangspunkt for en løsning, rejser tvivl om langtidsholdbarheden.

Der udestår stadig banale formaliteter og en række uafklarede spørgsmål, som giver kritikere og modstandere en forhalingstaktisk mulighed. Specielt har spørgsmålet om tilbagevenden af de internt fordrevne til deres hidtidige jord skabt uenighed internt i regeringen om, hvorvidt en jordreform først skulle afklares.

I praksis betyder den opnåede løsning, der er en minimumsløsning på de givne vilkår, at de væsentlige spørgsmål skal løses af den samme struktur, som ikke har formået det gennem de seneste mange år. Derfor er der stadig usikkerhed om fremtiden, og mange politikere er allerede begyndt at positionere sig med henblik på næste valg om fem år.

Et alternativ kunne have været en tidsbegrænset overgangsregering under ledelse af en neutral, uafhæn- gig person med mandat til at lede landet frem til et hurtigt valg, hvor reformprogrammet kunne have været hovedemnet for den politiske stillingtagen. Det ville imidlertid have forudsat en annullering af det netop afholdte valg, som ville have været uacceptabelt for det siddende styre.

\section{Zimbabwes dilemmaer}

Netop sidstnævnte løsningsmulighed har været i spil i Zimbabwe for at komme uden om en helt nødvendig 'regime change', som Kenya gennemgik tidligere, og som resultatet fra første valgrunde pegede frem mod. Det kan forklare nabostaternes valne holdning og den uhørte og retsstridige langsommelighed i at offentliggøre det valgresultat, som de fleste kendte allerede kort efter valget.

En overgangsregering kunne både have givet Mugabe mulighed for en hæderfuld sortie og en mulighed for at fastholde befrielsesbevægelsen ved magten og derved reducere risikoen for en militær magtovertagelse.

Som allerede anført har selve befrielsesideologien og befrielsesbevægelsens faste greb om magten udelukket en sådan løsning, som ikke indebærer 'regime change', men blot et generationsskifte inden for bevægelsen. Den hårde kerne omkring Mugabe med militæret i spidsen har vetoet selv denne be- 
skedne ændring og benhårdt krævet en ny valgrunde, hvor de velkendte manipulerende og voldelige midler skulle sikre befrielsesbevægelsens monopol på magten personificeret $\mathrm{i}$ genvalget af Mugabe.

At denne løsning ikke vil give nogen form for politisk legitimitet til styret og betyde en fortsat nedsmeltning af økonomien, ses der bort fra. Den givne ret til magten, der hentes fra befrielsesideologien, har førsteprioritet og bliver det eneste afgørende.

Det internationale samfund har ikke kunnet trænge igennem dette 'teflon-skjold'. Pressionsforsøgene fra den tidligere kolonimagt har kun gjort ondt værre, og alle havde været bedst tjent med tavshed fra britisk side i lyset af deres tidligere fejltagelser. Ligeledes har Kinas tavse og skjulte støtte her som i andre internationale krisesituationer reduceret betydningen af den vestlige pression. I stedet har opgaven som næunt været overdraget til den regionale organisation SADC, der som værende del af 'det befrielsesideologiske netværk' er veget tilbage for at støtte den nødvendige 'regime change', som kunne indebære risikoen for, at det skete på bekostning af befrielsesbevægelsen.

Stillet over for såvel en økonomisk som en politisk nedsmeltning begyndte denne enighed dog at krakelere i opløbet til anden valgrunde 27. juni 2008 (Den 22. juni meddelte oppositionens leder, Morgan
Tsvangirai, at han trak sig fra anden valgrunde efter chikane mod oppositionen. Mugabe blev derfor genvalgt uden modkandidat. Red.) specielt blandt de nyere statsledere, som har deres udgangspunkt i demokratiske valg. De har i stigende grad talt for en stærkere reaktion ved at inddrage AU og specielt formanden, Tanzanias præsident Kikwete, der har en dobbeltrolle gennem sit lands medlemskab af SADC

\section{Thabo Mbeki}

Alle bestræbelser stødte mod en barriere på grund af holdningen hos Sydafrikas præsident Thabo Mbeki, der stædigt har benægtet, at der overhovedet er tale om en krise i Zimbabwe.

Det er genstand for en ivrig debat, hvordan Mbekis holdning skal forstås og forklares. Han er stærkt rodfæstet i den sydafrikanske befrielsesbevægelse ANC og kan ikke acceptere noget alternativ hertil hverken i Sydafrika eller Zimbabwe. For Mbeki står Mugabe som frihedshelten, der i modsætning til Tsvangirai aktivt deltog i guerillabevægelsen.

Om det er Mugabe som person eller som symbol, der er afgørende, står ikke helt klart. Langsigtet synes Mbeki at arbejde for en løsning, der sikrer, at Mugabe får en ærefuld sortie, blot ZANU-PF fastholder sin ubestridelige ret til at sidde på magten. 


\section{HOLGER BERNT HANSEN}

Derfor støttede han fortsat med sin kendte stædighed den vingeskudte demokratiske proces og et genvalg af Mugabe som den nødvendige garant for, at befrielsesbevægelsen forblev ved magten.

Det er dog et spørgsmål, om Mbeki ikke er ved at blive overhalet indenom af andre begivenheder, således at hans veto-agtige position mod selv en begrænset form for 'regime change' ikke kan opretholdes. Mugabes klare nederlag ved valget 29 . marts skabte en ny situation, som kræver stadig grovere midler for at fastholde magten.

Som nævnt er enigheden i SADC og i en bredere afrikansk sammenhæng ved at krakelere, og Mbeki kommer under stadig stærkere kritik for sin politik fra stadig mere højttalende kredse i selve Sydafrika, heriblandt fra hans sandsynlige efterfølger som præsident og fra havnearbejdere, der har nægtet at lodse en våbenleverance fra Kina til Zimbabwe.

Der er ved at opstå et stadig større spænd mellem en ubrydelig fastholden ved og loyalitet mod befrielsesideologien og almindeligt accepterede demokratiske principper.

Et sidste grundskud mod Mbekis politik kan blive de omfattende angreb i slutningen af maj på de op til fem millioner flygtninge i Sydafrika, hvoraf langt størstedelen er fra Zimbabwe.

De forklares som et uheldigt udbrud af xenofobi, og de undskyldes og beklages som et alvorligt brud på et grundlæggende princip i Sydafrikas eksistens, at give asyl til forfulgte parallelt med den gæstfrihed, som ANC's tilhængere selv nød godt af under Apartheid.

Det er således karakteristisk, at den første forklaring hentes fra antiapartheid-bevægelsen og befrielsesideologi-komplekset. Men da det især er de talrige flygtninge fra Zimbabwe, der ses som årsagen til social uro og kriminalitet, vil næste reaktion uden tvivl finde årsagen i Mbekis politik og pege på, at han i stedet for en ideologisk baseret støtte til fastholdelse af et bestemt regime, der i stort omfang har tvunget egne borgere ud af landet, skulle have prioriteret den økonomiske udvikling. Det kunne have fastholdt flygtningene hjemme til gavn for landets og regionens fredelige udvikling, og jæunsides hermed have støttet 'regime change' på demokratisk grundlag.

Holger Bernt Hansen er professor ved Center for Afrikastudier, Københavns Universitet. 